(10.21704/pja.v4i1.1462

http://revistas.lamolina.edu.pe/index.php/jpagronomy/index

(C) The authors. Published by Universidad Nacional Agraria La Molina

\title{
Lead Phyto extraction in the Huachipa Zoological Park through the use of Tagetes erecta associated with a mycorrhiza and EDTA
}

\author{
Fitoextracción de plomo en el Parque Zoológico de Huachipa mediante el uso de Tagetes erecta \\ asociado a micorrizas y EDTA
}

Carrera, O. $\left({ }^{(}\right) *$; Tello, L. $\left({ }^{2}\right)$

*Corresponding author: ocarrera.romero@gmail.com

https://orcid.org/0000-0002-4309-7522

\begin{abstract}
Phytoremediation is a potentially less costly approach to treat contaminated soil. Here, the phytoremediation capacity of marigold (Tagetes erecta) in conjunction with EDTA and mycorrhizae was analyzed. Specifically, the ability of the marigold to extract lead from contaminated soils in the Bird Forest Zone of the Huachipa Zoological Park (PZH) was evaluated. Marigold was planted in main areas of interest within the PZH. Plants were treated with different concentrations of mycorrhizae ( 0 and $0.5 \mathrm{~g} / \mathrm{kg})$ and EDTA $(0,0.5$ and $1 \mathrm{mg} / \mathrm{kg})$ and later analyzed by atomic absorption spectrophotometry for lead concentrations in the aerial parts and roots of the plants at the end of the experiment. We show that marigold has the ability to extract lead; and under the conditions of the experiment, mycorrhizae did not improve the extraction efficiency. However, EDTA did increase the amount of lead extracted, thus affecting the physiological development of the plant.
\end{abstract}

Keywords: Phytoextraction, mycorrhizae, EDTA, lead, recreational parks

\section{Resumen.}

El uso de la fitorremediación para solucionar problemas de contaminación de suelos ha aparecido como una alternativa de menor costo a los tratamientos convencionales. En base a esto, se analizó la capacidad fitorremediadora del marigold (Tagetes erecta) asistida con EDTA y micorrizas. Específicamente se evaluó la capacidad del marigold para extraer plomo de los suelos contaminados en la Zona del Bosque de Aves del Parque Zoológico de Huachipa (PZH). Para esto se realizó la plantación de marigold en las zonas de mayor interés dentro del PZH, con tratamientos de diferentes concentraciones de micorrizas $(0$ y $0,5 \mathrm{~g} / \mathrm{kg})$ y $\operatorname{EDTA}(0,0,5$ y $1 \mathrm{mg} / \mathrm{kg})$, para posteriormente ser analizadas mediante espectrofotometría de absorción atómica y analizar la concentración de plomo en las partes aéreas y radiculares de las plantas al final del experimento. Con esta investigación se demostró que el marigold es una planta con capacidad de extracción de plomo, y que si bien, bajo las condiciones del experimento, las micorrizas no presentaron una mejora en la eficiencia de extracción, el EDTA si aumentó la cantidad de plomo extraído, por lo que el desarrollo fisiológico de la planta se ve afectado.

Palabras claves: Fitoextracción, especie acumuladora, micorrizas, EDTA, plomo, parques recreacionales

\section{Introduction}

Soil contamination is defined as the presence of contaminants in soil at concentrations high enough to cause threats to ecological quality and / or present risks to human health (Duarte et al., 2017). One of the most common soil contaminants is lead, which is toxic in small doses, and can affect almost all organs and systems in the human body, especially the nervous system. Its main route of bioavailability is through the soil and dust (Corzo \& Velásquez, 2014).
In recent years, phytoremediation has emerged as an approach that takes advantage of the ability of certain plants to absorb, accumulate, metabolize, volatilize, or stabilize contaminants such as heavy metals, organic compounds, and others that are present in the soil, air, water, or sediments (Delgadillo-López et al., 2011). Marigold (Tagetes erecta) can extract metals from soil, and thus it can be used for phytoremediation (Castillo et al., 2011; Shah et al., 2017). This plant is well-adapted

\footnotetext{
${ }^{1}$ Universidad Nacional Agraria la Molina. Lima, Perú: *ocarrera.romero@gmail.com https://orcid.org/0000-0002-4309-7522

${ }^{2}$ Universidad Nacional Agraria la Molina. Lima, Perú. 1tello@lamolina.edu.pe https://orcid.org/0000-0002-1335-062X.
} 
to the coastal climatic conditions of Peru, its transplants produce high seedling yields, and its harvest yields are high (Mendez, 2009).

To improve the efficiency of phytoremediation, other elements can be added, such as arbuscular mycorrhizae, which mitigate stress and increase plant growth in sites heavily contaminated with heavy metals (Duñabeitia et al., 2004; Gaur \& Adholeya, 2004; Amna et al., 2015). Likewise, EDTA is a chelating agent that can be used to solubilize different metals in soils and enhance their absorption and translocation in plants with high rates of biomass production (Huang et al., 1997; Lombi et al., 2001).

The present study aimed to determine the efficiency of lead extraction of marigold (Tagetes erecta) associated with mycorrhizae and/or EDTA in the soil of the Bird Forest Zone of the Huachipa Zoo.

\section{Materials and Methods}

\section{Study area}

Previous research has demonstrated soil contamination in the so-called "Bosque de aves" and its surroundings in the Zoological Park of Huachipa (Tello et al., 2018), district of Ate, province of Lima, department of Lima $\left(12^{\circ} 0{ }^{\prime} 51.88^{\prime}\right.$ 'S, 76 53 '44. 36”W) (Figure 1). The study area is close to the bed of the Rímac River, which is contaminated due to the various activities that take place around it. For example, Juárez (2006) mentioned that the Rímac River basin supports intense mining activity in the middle and upper part of the basin, resulting in a high risk of contamination by heavy metals and posing a negative impact on the environment and human health.

\section{Soil sampling}

An initial sampling was carried to corroborate the presence of lead in the soil within the study site. Twelve $10-\mathrm{cm}$ deep core soil samples were collected to determine the lead content of the soil and to confirm previous data. The sampling procedure is as follows: The surface vegetation was cleared and approximately $0.5 \mathrm{~kg}$ (weight required for heavy metal analysis) of samples were collected and stored in properly labeled Ziploc bags. We followed sampling guidelines published in the "Guía para Muestreo de Suelos" of MINAM (2014), which considers sampling depths between 0 and $10 \mathrm{~cm}$ as those most relevant for oral or dermal contact of contaminants. Thus, we sampled soil at a depth of $10 \mathrm{~cm}$

\section{Determination of metals in the soil}

The soil samples were sent to the Laboratorio de Suelos, Plantas, Aguas y Fertilizantes de la UNALM (LASPAF-UNALM) for lead analysis using atomic absorption spectrophotometry (PerkinElmer Analyst 200 Spectrophotometer). It should be noted that this laboratory follows a method of analysis established for Peruvian soil by the EQS (Supreme Decree N ${ }^{\circ}$ 011-2017-MINAM) and which follows the EPA 3050 and EPA 3051 guidelines.

\section{Preparation of Seedlings of Tagetes erecta}

In May, Tagetes erecta was sown in a greenhouse located within the UNALM and then transported to the study area. One thousand seeds of yellow Tagetes erecta were germinated in trays with 72 to 200 holes containing a mixture of river sand and sifted moss in a $1: 3$ ratio. The germination percentage of the seeds was $80 \%$.

Seeds were planted at the rate of 1 seed/hole in the trays, being careful not to place them too deep or too close

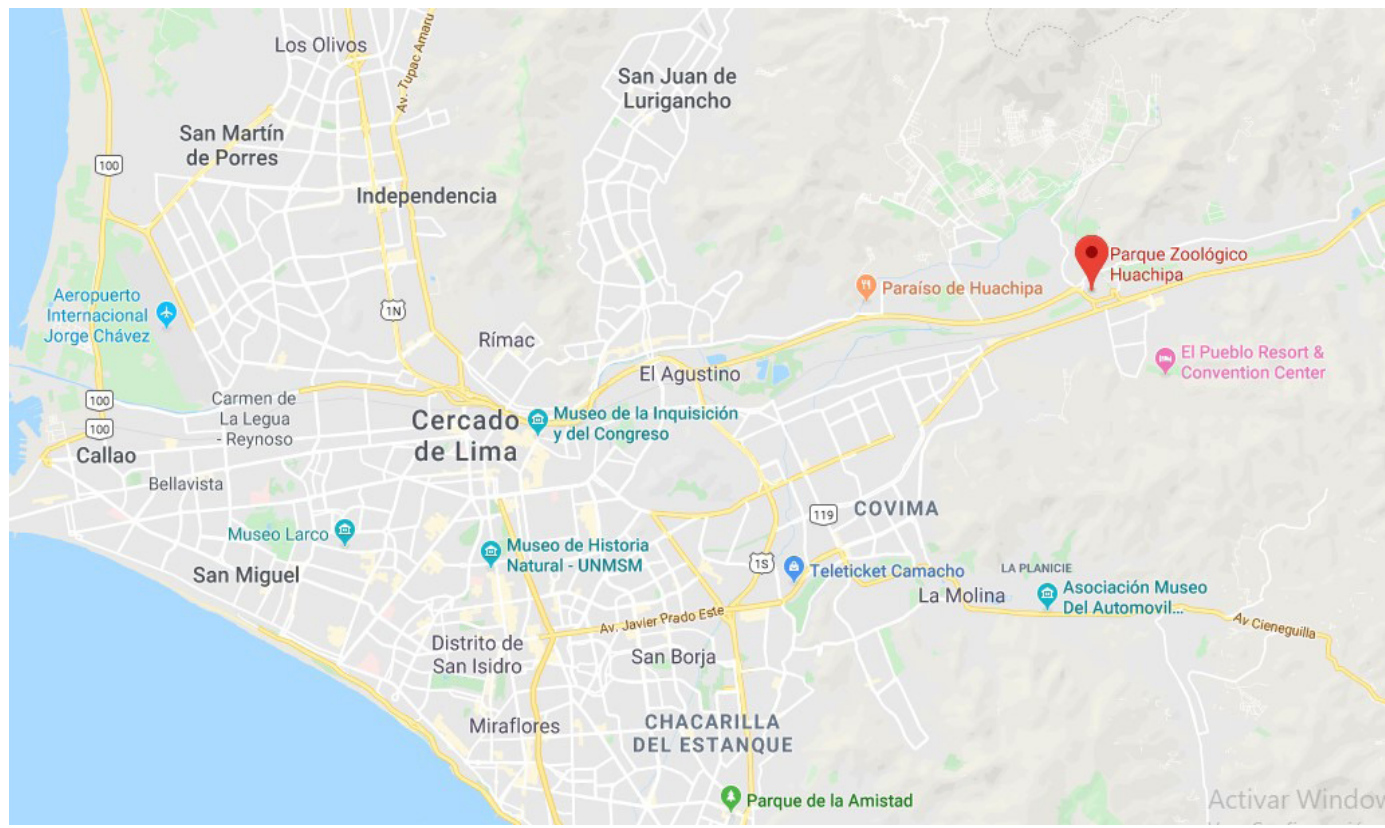

Figure 1. Map of the project location 
to the surface, either of which could affect germination success. The trays were kept inside the Laboratorio de Fertilidad de la Universidad Nacional Agraria la Molina, and were watered 3 times a week until the appearance of the first pair of true leaves.

\section{Transfer to bags and application of Mycorrhizae}

After 2 weeks or after the development of first pair of true leaves, seedlings were transferred into $6 \times 6$-inch low-density polyethylene bags from PlastPeru in which holes were punched to allow aeration and drainage of the substrate. The substrate consisted of a mixture of compost, previously sifted moss, and farm soil in a 4:3:3 ratio. Each culture bag was filled with approximately half a kilogram of substrate. In some of the bags, Glomus intaradices was added according to the quantities specified in Table 1. The seedlings were then carefully removed from the germination tray and transplanted to the culture bags. In this manner, the mycorrhizae were in contact with the roots of the plants. Plants were irrigated 3 times a week until the development of the second pair of true leaves, at which point they were ready for field transfer.

Table 1: Treatments applied

\begin{tabular}{lll}
$\begin{array}{l}\text { Treatment } \\
\text { number }\end{array}$ & $\begin{array}{l}\text { Amount of EDTA } \\
(\mathrm{g} / \mathrm{kg})\end{array}$ & $\begin{array}{l}\text { Amount of } \\
\text { mycorrhiza (Glomus } \\
\text { intaradices) }(\mathrm{g})\end{array}$ \\
\hline 1 & 0 & 0 \\
2 & 0 & 1.5 \\
3 & 0.5 & 0 \\
4 & 0.5 & 1.5 \\
5 & 1 & 0 \\
6 & 1 & 1.5 \\
\hline
\end{tabular}

Table 2: Location of treatments

\section{Transfer of plants to the field}

In June, after all plants had developed the second pair of true leaves, they were transported to the study site at the Zoological Park of Huachipa

Before transplanting, samples were randomly collected from each of the 3 areas of interest and composited into $1 \mathrm{~kg}$ of soil that was stored in a Ziploc bag. This randomized, composite sample was analyzed to obtain the general physicochemical characteristics of the study area. The experiment was arranged in a completely randomized block with two factors (amount of mycorrhizae and amount of EDTA added). The treatments and their respective distribution in the areas of the Park are shown in Table 2, Each treatment comprised 20 plants, distributed in 5 columns and 4 rows, spaced $20 \mathrm{~cm}$ apart. Therefore, each experimental unit is approximately $0.8 \mathrm{~m}^{2}$. All plants were transplanted with a hand shovel to a depth of approximately $10 \mathrm{~cm}$. Each plot was irrigated with 4L of well water per session, with a total of 4 irrigation sessions per week.

\section{Application of EDTA}

At the third irrigation session, the plants were considered to have already adapted to their new environment. At this point, EDTA was added according to the treatments and quantities specified in Table 1. However, because high doses can negatively affect the growth of plants, EDTA was added in small doses. Initially, EDTA was added at a rate of $22.4 \mathrm{mg}$ per $0.8 \mathrm{~m}^{2}$ of each treatment, which was subsequently reduced to $11.2 \mathrm{mg}$ per irrigation session. However, all doses were not fully aplied because the field plants had to be removed weeks before due to loss of samples.

Before and after each irrigation session, soil conductivity was measured using a conductometer from Maruplast, to measure any changes in soil salinity.

\begin{tabular}{|c|c|c|c|c|c|c|c|}
\hline \multirow{2}{*}{ Treatment } & \multirow{2}{*}{ Replicate } & \multicolumn{2}{|c|}{ Coordinates } & \multirow{2}{*}{ Treatment } & \multirow{2}{*}{ Replicate } & \multicolumn{2}{|c|}{ Coordinates } \\
\hline & & South & West & & & South & West \\
\hline 1 & \multirow{6}{*}{$\mathrm{A}$} & \multirow{6}{*}{$12^{\circ} 0.843^{\prime} \mathrm{S}$} & \multirow{6}{*}{$76^{\circ} 53.690^{\prime} \mathrm{W}$} & 1 & \multirow{4}{*}{$\mathrm{C}$} & \multirow{4}{*}{$12^{\circ} 0.824^{\prime} \mathrm{S}$} & \multirow{4}{*}{$76^{\circ} 53.676^{\prime} \mathrm{W}$} \\
\hline 2 & & & & 2 & & & \\
\hline 3 & & & & 3 & & & \\
\hline 4 & & & & 4 & & & \\
\hline 5 & & & & 5 & \multirow{2}{*}{$\mathrm{C}$} & \multirow{2}{*}{$12^{\circ} 0.823^{\prime} \mathrm{S}$} & \multirow{2}{*}{$76^{\circ} 53.680^{\prime} \mathrm{W}$} \\
\hline 6 & & & & 6 & & & \\
\hline 1 & \multirow{3}{*}{$\mathrm{B}$} & \multirow{3}{*}{$12^{\circ} 0.827^{\prime} \mathrm{S}$} & \multirow{3}{*}{$76^{\circ} 53.668^{\prime} \mathrm{W}$} & 1 & \multirow{3}{*}{$\mathrm{D}$} & \multirow{3}{*}{$12^{\circ} 0.832^{\prime} \mathrm{S}$} & \multirow{3}{*}{$76^{\circ} 53.697^{\prime} \mathrm{W}$} \\
\hline 2 & & & & 2 & & & \\
\hline 3 & & & & 3 & & & \\
\hline 4 & \multirow{3}{*}{$\mathrm{B}$} & \multirow{3}{*}{$12^{\circ} 0.827^{\prime} \mathrm{S}$} & \multirow{3}{*}{$76^{\circ} 53.678^{\prime} \mathrm{W}$} & 4 & \multirow{3}{*}{$\mathrm{D}$} & \multirow{3}{*}{$12^{\circ} 0.838^{\prime} \mathrm{S}$} & \multirow{3}{*}{$76^{\circ} 53.697^{\prime} \mathrm{W}$} \\
\hline 5 & & & & 5 & & & \\
\hline 6 & & & & 6 & & & \\
\hline
\end{tabular}




\section{Pest control}

To control pests, FUERZA200 SC insecticide(concentrated suspension) made by Point Andina S.A was used. The active ingredient of this insecticide is Fipronil, which attacks the central nervous system of insects. However, the mining fly (Liriomyza huidobrensis) persisted in attacking the experimental plants, affecting their development.

\section{Plant harvest and post-harvest soil sampling}

Two months after transplanting, the plants were harvested using landscaping scissors. Plants were cut above the root. Both the aerial parts and the roots were stored in Ziploc bags. All transplanted plants were harvested because of losses due to pests. After harvesting, soil samples were collected from each treatment and then stored in labeled Ziploc bags. All samples were transported to the National Agrarian University of La Molina. Soil and plant samples were sent to the Laboratorio de Suelos, Plantas, Agua y Fertilizantes, and to the Laboratorio de Fertilidad, respectively.

\section{Determination of lead content in plants}

After harvesting, plants were separated and the lengths of the aerial parts and roots, and number of leaves were measured. To determine the lead content in the plant, we followed the EPA 3050 methodology. Briefly, the aerial parts and roots of each sample were carefully washed, first with tap water and then with deionized water. Then the aerial parts and roots of each treatment were placed in their respective paper bags and then heated in an oven for $48 \mathrm{~h}$ at $70^{\circ} \mathrm{C}$. The dry weight of each sample was recorded and dried samples were ground using a mortar and pestle.

Two grams of ground material were placed inside flasks. In treatments that yielded insufficient biomass $(<$ $2 \mathrm{~g})$ all the dust resulting from the grinding was placed. The samples were placed in an oven $\left(70^{\circ} \mathrm{C}\right)$ again for approximately 8 hours. Subsequently, $25 \mathrm{ml}$ of solution of
1:1 $\mathrm{HNO}_{3}$ and $1: 1 \mathrm{H}_{2} \mathrm{SO}_{4}$ was added to each of the flasks; in the case of flasks containing samples that weighed less than $2 \mathrm{~g}$, only $10 \mathrm{ml}$ of solution was added. Next, the flasks were heated on a hot plate at $170^{\circ} \mathrm{C}$ to continue the digestion process. The samples were digested until it all visible particles had dissolved into solution. Subsequently, the flasks were removed from the plate, allowed to cool, and then filtered through a Whatman No. 41 filter paper. Filtrates were transferred to centrifuge tubes, where they were stored and until subsequent lead analysis by atomic absorption spectrophotometry.

\section{Determination of translocation factors}

The plants were appraised for their ability to translocate heavy metals from the roots to the aerial parts (Mattina et al., 2003, cited by Marchiol et al., 2004). The following formula was used to determine the translocation factor:

$$
\text { Translocation factor }(F t)=\frac{[\text { Metal }] \text { in aerial part }}{[\text { Metal }] \text { in root }}
$$

\section{Statistical Design}

The data on lead concentrations in the plant, roots, and aerial parts, and plant height were analyzed via normality test and equality of varianeces to evaluate the assumptions of normality and homogeneity, respectively. Both assumptions were met. A p-value of 0.05 was considered significant. All statistical tests were carried out using Minitab 2019 software from Minitab Inc. developer.

\section{Results and Discussion}

\section{Initial lead content in the study area}

The results of lead analysis are shown in Table 3. In all areas, spots with high lead content were observed.

Table 3: Initial lead content in the study area

\begin{tabular}{|c|c|c|c|c|}
\hline \multirow{2}{*}{ Code } & \multirow{2}{*}{ Zone } & \multicolumn{2}{|c|}{ Coordinates } & \multirow{2}{*}{$\mathrm{Pb}$ ppm } \\
\hline & & Latitude & Length & \\
\hline ZA-1 & Behind the atmosphere of the Aliblanca turkey & $12^{\circ} 00,825$ & $76^{\circ} 53,672$ & 348.92 \\
\hline ZA-2 & Behind the horned owl environment & $12^{\circ} 00,823$ & $76^{\circ} 53,672$ & 336.79 \\
\hline ZA-3 & Between the atmosphere of the spectacled owl and blue-headed macaw & $12^{\circ} 00,826$ & $76^{\circ} 53,665$ & 357.93 \\
\hline ZA-4 & Next to the environment of Cucacu & $12^{\circ} 00,822$ & $76^{\circ} 53,673$ & 393.96 \\
\hline ZBA-1 & Pacarana environment & $12^{\circ} 04,937^{\prime}$ & $76^{\circ} 56,866^{\prime}$ & 41.84 \\
\hline ZBA-2 & Exterior of the environment of Pacarana & $12^{\circ} 00,828^{\prime}$ & $76^{\circ} 53,702$ & 307.91 \\
\hline ZBA-3 & Facing the environment of Pacarana & $12^{\circ} 00,844^{\prime}$ & $76^{\circ} 53,702$ & 235.35 \\
\hline ZBA-4 & Macaw atmosphere & $12^{\circ} 00,845^{\prime}$ & $76^{\circ} 53,696$ & 269.39 \\
\hline ZBA-5 & Near the entrance - right side & $12^{\circ} 00,854^{\prime}$ & $76^{\circ} 53,703$ & 480.55 \\
\hline ZE-1 & In front of the camel quarantine zone & $12^{\circ} 00,853$ & $76^{\circ} 53,682$ & 562.05 \\
\hline ZE-2 & In front of the environment of smaller felines & $12^{\circ} 00,857$ & $76^{\circ} 53,682$ & 179.29 \\
\hline ZE-3 & To the left side of smaller felines & $12^{\circ} 00,861^{\prime}$ & $76^{\circ} 53,691^{\prime}$ & 27.49 \\
\hline
\end{tabular}


Specifically, ZE-1, ZBA-5, ZA-4 had lead concentrations of $562.05,480.55$, and $393.96 \mathrm{ppm}$, respectively, which were the highest measurements we obtained for soil in the study area. Most of these values are above the environmental quality standard established for park floors (i.e., $140 \mathrm{ppm}$ ). These results confirm findings of a previous research carried out in the Zoological Park of Huachipa, by Tello et al. (2018) who observed that soils in the park, specifically in the area of the bird forest, are contaminated by lead. This is likely due to sediments left by waters of the Rímac River, which tends to overflow and flood this area (Tello et al., 2018).

\section{Physical-chemical characterization of the treated soil}

Table 4 shows the characteristics of the soil of the Zoological Park of Huachipa. The soil texture is frank, with a neutral $\mathrm{pH}$, slight salinity, and with a high level of organic matter $(>4 \%)$. Analyses of other metals such as $\mathrm{Cd}$ and $\mathrm{Cr}$ show generally low concentrations that do not exceed the values established by the ECA (Cd: $10 \mathrm{ppm}$ and Cr: 400 ppm).

Table 4: Characteristics of the soil of Huachipa Zoological Park

\begin{tabular}{|c|c|c|c|}
\hline Parameter & & Units & Value \\
\hline $\mathrm{pH}(1: 1)$ & & & 7.03 \\
\hline C.E. (1:1) & & $\mathrm{dS} / \mathrm{m}$ & 2.92 \\
\hline $\mathrm{CaCO}_{3} \%$ & & $\%$ & 1.3 \\
\hline M.O. \% & & $\%$ & 4.89 \\
\hline P ppm & & Ppm & 50.3 \\
\hline $\mathrm{K}$ ppm & & Ppm & 432 \\
\hline \multirow{3}{*}{ Mechanical Analysis } & Sand & $\%$ & 51 \\
\hline & Silt & $\%$ & 34 \\
\hline & Clay & $\%$ & 15 \\
\hline Clase Textural & & & Fr. \\
\hline CIC & & $\mathrm{meq} / 100 \mathrm{~g}$ & 14.08 \\
\hline \multirow{5}{*}{ Changeable Cations } & $\mathrm{Ca}^{+2}$ & $\mathrm{meq} / 100 \mathrm{~g}$ & 11.09 \\
\hline & $\mathrm{Mg}^{+2}$ & $\mathrm{meq} / 100 \mathrm{~g}$ & 1.53 \\
\hline & $\mathrm{K}^{+}$ & $\mathrm{meq} / 100 \mathrm{~g}$ & 0.88 \\
\hline & $\mathrm{Na}^{+}$ & $\mathrm{meq} / 100 \mathrm{~g}$ & 0.57 \\
\hline & $\mathrm{Al}^{+3}+\mathrm{H}^{+}$ & $\mathrm{meq} / 100 \mathrm{~g}$ & 0 \\
\hline Sum of Cations & & $\mathrm{meq} / 100 \mathrm{~g}$ & 14.08 \\
\hline Sum of Bases & & $\mathrm{meq} / 100 \mathrm{~g}$ & 14.08 \\
\hline$\%$ Sat. Of Bases & & $\%$ & 100 \\
\hline $\mathrm{Fe}$ & & Ppm & 50.4 \\
\hline $\mathrm{Cu}$ & & Ppm & 34.4 \\
\hline $\mathrm{Mn}$ & & Ppm & 4.24 \\
\hline $\mathrm{Zn}$ & & Ppm & 44.8 \\
\hline $\mathrm{B}$ & & ppm & 3.8 \\
\hline $\mathrm{Pb}$ & & ppm & 176.21 \\
\hline $\mathrm{Cd}$ & & ppm & 6.47 \\
\hline $\mathrm{Cr}$ & & ppm & 17.59 \\
\hline
\end{tabular}

Table 5 shows the concentrations of lead in the treated soils before planting. The average values vary between 167.83 and $219.27 \mathrm{ppm}$, which are close to the value of lead concentration in the composite sample (176.21 ppm). Of the 24 soil samples evaluated, 21 have lead concentrations that exceed the ECA for park soils (D.S. No. 011-2017-MINAM). The three samples, whose lead concentrations are below the RCT, correspond to samples collected from the Bosque de Aves.

Table 6 shows the concentrations of lead in treated soils after harvest. In the majority of cases, the concentration of lead in the soil increased, contradicting previous research on phytoremediation that report a decrease in the concentration of lead in the soil post-remediation. A possible explanation for our findings lies in the use of water from the Rímac River by the park managers to irrigate the plantations around the Bird Forest on 4 occasions. Because, the sediments of the Rímac River are contaminated by lead, using the river water for irrigation could have contaminated our study site as suggested by Tello et al. (2018). Moreover, the damping effect of soils and its high organic matter content $(4.89 \%)$ may also contribute to higher lead concentrations.

The Rímac River water quality reports (SEDAPAL, 2009) show that in months such as January and February, lead concentrations increase above the ECA values in stations close to the PZH; however, in other months, the lead concentrations remain below the threshold limit. These observations suggest that lead concentrations in the Rímac River increase periodically, probably due to the effluents of the industries that are close to the Rímac River basin.

\section{Tagetes erecta development \\ Morphological parameters}

Figure 2 shows that treatment 1 and 2 produced the tallest plants, while treatments 3 and 4 produced plants that were slightly shorter than treatment 5 and 6 plants.

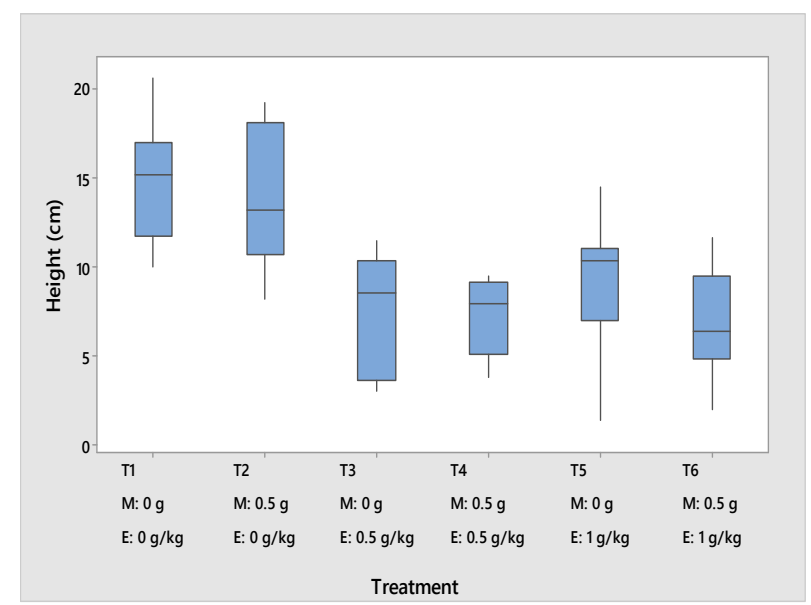

Figure 2. Plant heights in the different treatments. M, mycorrhizae; E, EDTA 
Table 5: Initial concentrations of lead in the treated soils

\begin{tabular}{|c|c|c|c|c|c|c|c|}
\hline \multirow{3}{*}{ Treatments } & \multirow{3}{*}{$\begin{array}{c}\text { EDTA } \\
(\mathrm{mg})\end{array}$} & \multirow{3}{*}{$\begin{array}{l}\text { Mycorrhiza } \\
\text { (mg/kg soil) }\end{array}$} & \multicolumn{4}{|c|}{ Repetitions } & \multirow{3}{*}{ Average } \\
\hline & & & $\mathbf{A}$ & B & $\mathrm{C}$ & D & \\
\hline & & & \multicolumn{4}{|c|}{$\mathrm{Pb}(\mathrm{ppm})$} & \\
\hline 1 & 0 & 0 & 279.56 & 214.44 & 217.00 & 121.06 & 208.02 \\
\hline 2 & 0 & 0.5 & 180.88 & 248.63 & 231.63 & 114.25 & 193.85 \\
\hline 3 & 0.5 & 0 & 206.38 & 235.75 & 178.75 & 231.63 & 213.13 \\
\hline 4 & 0.5 & 0.5 & 150.25 & 154.56 & 177.25 & 189.25 & 167.83 \\
\hline 5 & 1 & 0 & 228.13 & 193.5 & 174.19 & 217.5 & 203.33 \\
\hline 6 & 1 & 0.5 & 346.13 & 194.19 & 199.63 & 137.13 & 219.27 \\
\hline
\end{tabular}

Table 6: Final concentrations of lead in the treated soils

\begin{tabular}{|c|c|c|c|c|c|c|c|}
\hline \multirow{3}{*}{ Treatments } & \multirow{3}{*}{ EDTA (mg) } & \multirow{3}{*}{$\begin{array}{l}\text { Mycorrhiza } \\
\text { (mg/kg soil) }\end{array}$} & \multicolumn{4}{|c|}{ Repetitions } & \multirow{3}{*}{ Average } \\
\hline & & & $\mathbf{A}$ & B & $\mathrm{C}$ & D & \\
\hline & & & \multicolumn{4}{|c|}{$\mathrm{Pb}(\mathrm{ppm})$} & \\
\hline 1 & 0 & 0 & 385.88 & 153.63 & 235.75 & 78.81 & 213.52 \\
\hline 2 & 0 & 0.5 & 384.25 & 167 & 253 & 174.63 & 244.72 \\
\hline 3 & 0.5 & 0 & 227.13 & 139.63 & 199.25 & 307.56 & 218.39 \\
\hline 4 & 0.5 & 0.5 & 166.19 & 141.38 & 248.63 & 258.69 & 203.72 \\
\hline 5 & 1 & 0 & 124.56 & 312 & 179.63 & 172.38 & 197.14 \\
\hline 6 & 1 & 0.5 & 119.5 & 163 & 276.25 & 173.56 & 183.08 \\
\hline
\end{tabular}

Similarly, Figure 3 shows that as in the case with plant heights, treatments 1 and 2 produced the longest roots while treatments 3 and 4 produced the shortest roots. However, for the same concentration of EDTA, the longest roots occurred in the presence of mycorrhizae.

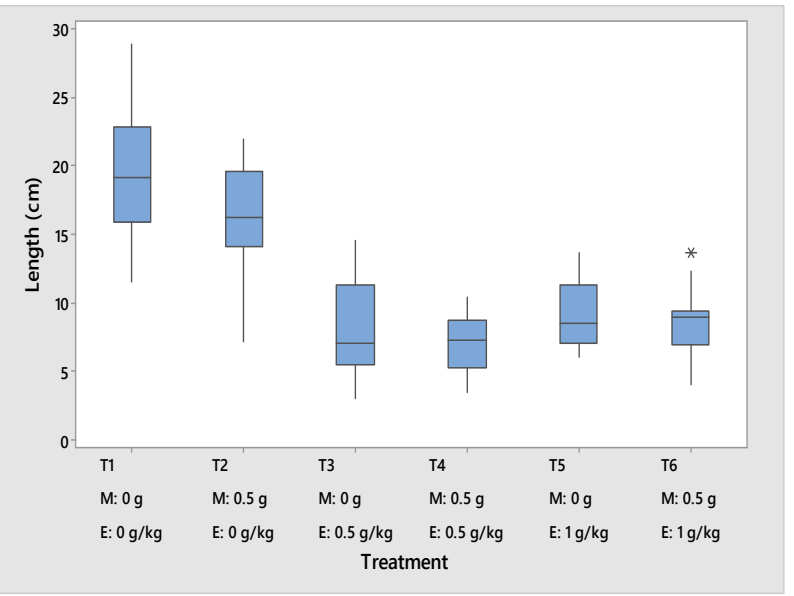

Figure 3. Root lengths of plants in the different treatments. M, mycorrhizae; E, EDTA; the asterisk indicates values that are far from normal distribution.

Statistical analysis indicates that neither mycorrhizae concentration ( 0 and $1.5 \mathrm{~g} / \mathrm{kg}$ of soil) nor EDTA $\mathrm{x}$ Mycorrhiza interaction significantly influenced plant height and root length. However, significant differences were found between plant height and root length in treatments with different concentrations of EDTA $(0,0.5$ and $1 \mathrm{~g} / \mathrm{kg}$ of soil). In the case of root lengths, significant differences were found between the factors (mycorrhizae and EDTA) and their interaction, indicating that mycorrhizae and EDTA affect root length. In cases where different concentrations of mycorrhizae produced no effect on root length, this may indicate that fungi did not colonize plant roots under the soil conditions presented in Table 4.

Treatments 3, 4, 5, and 6 produced shorter plants; this may be due to the presence of EDTA, which enabled the plants to extract more lead from the soil, leading to a higher concentration of the contaminant in the plant. Thus, the physiological development of the plants in these treatments was negatively affected. This confirms previous research carried out by Sinhal et al. (2009), who reported that marigold plants treated with EDTA accumulated more metals but also showed a great reduction in growth. In general, treatments with EDTA showed reduced growth in both the aerial and belowground parts of the plant. This may be because chelating agents usually produce symptoms of severe phytotoxicity in plants (Ebbs \& Kochian, cited by Diez, 2008), since they increase the extraction of lead, causing stunted growth.

\section{Lead Extraction in Tagetes erecta}

The concentrations of lead in the aerial parts of the plants in each treatment are presented in Figure 4. Treatments 1 and 2 produced the least amounts of lead accumulation in the aerial parts, while treatments 3 and 4 produced the highest concentrations of lead. In the case of the roots (Figure 5), treatments 1 and 2 again produced the least amount of lead accumulation, while treatments 3 and 4 produced the highest concentrations of lead.

Statistical analysis indicates that neither mycorrhizae concentration ( 0 and $1.5 \mathrm{~g} / \mathrm{kg}$ of soil) nor the EDTA $\mathrm{x}$ 
Mycorrhiza interaction produced significant differences in lead concentrations within the plant (both aerial parts and roots).

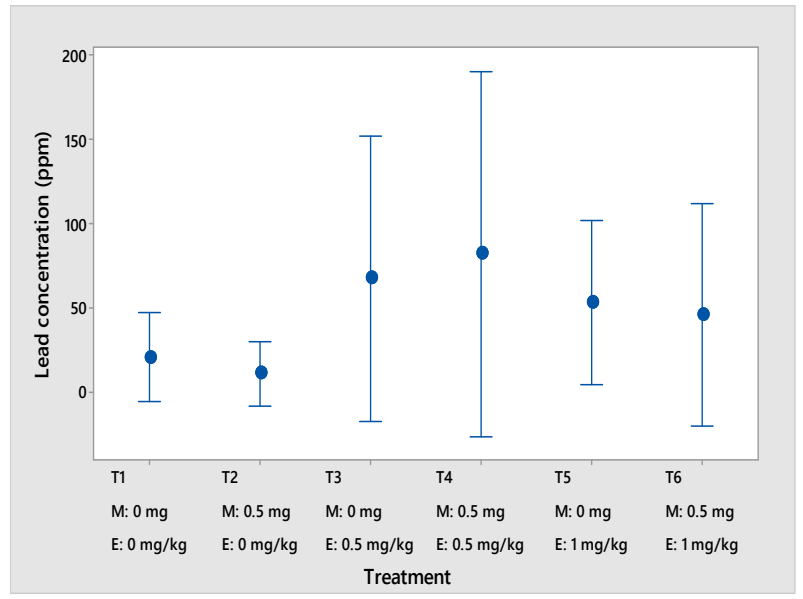

Figure 4. Lead concentrations in the aerial parts of the treated plants

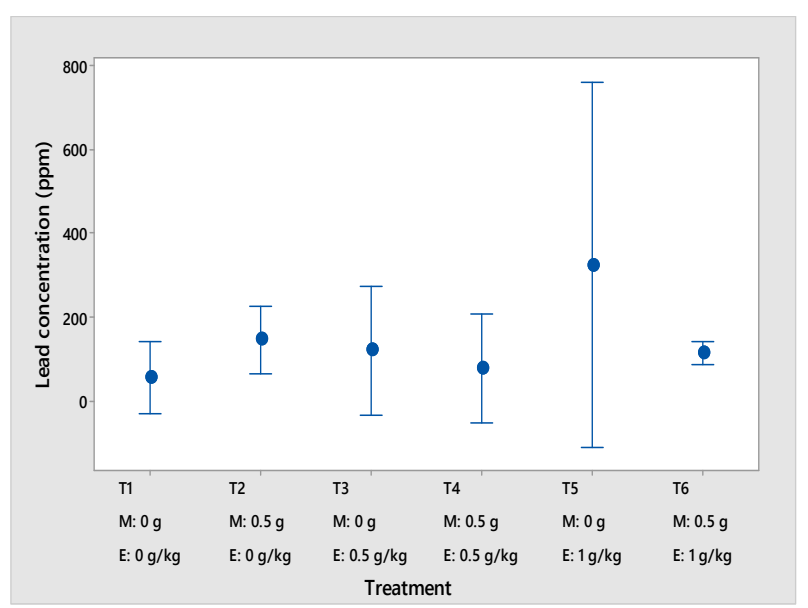

Figure 5. Lead concentrations in the roots of the treated plants

\section{Determination of translocation factors}

Table 7 shows the translocation factors associated with each treatment in the experiment. The results show that the translocation factor never exceeds the value of 1 . A plant is considered hyperaccumulating when its translocation factor exceeds 1, meaning the plant possesses a great capacity to transport metals from the roots to the aerial parts (Zhao, 2002).

\section{Conclusions}

According to the results obtained in the present investigation, we can draw the following conclusions:

-Marigold has the ability to extract lead from soil; however, none of the treatments had a translocation factor greater than 1; therefore, this species is not considered as hyperaccumulative under the conditions of the experiment.
Table 7: Translocation factors in each treatment.

\begin{tabular}{cccccc}
$\begin{array}{c}\text { Treat- } \\
\text { ment }\end{array}$ & $\begin{array}{c}\text { Myco- } \\
\text { rrhizae }\end{array}$ & EDTA & $\begin{array}{c}\text { Repeti- } \\
\text { tion }\end{array}$ & $\begin{array}{c}\text { Translocation } \\
\text { Factor }\end{array}$ & Average \\
\hline \multirow{2}{*}{ T1 } & 0 & 0 & B & 0.3 & 0.49 \\
& & & C & 0.99 & \\
\hline \multirow{2}{*}{ T2 } & 0 & 0.5 & B & 0.26 & 0.50 \\
& & & C & 0.34 & \\
\hline & & & A & 0.51 & \\
T3 & 0 & 1 & B & 0.35 & 0.47 \\
& & & C & 0.55 & \\
\hline \multirow{2}{*}{ T4 } & \multirow{2}{*}{0.5} & 0 & A & 0.19 & 0.16 \\
& & & C & 0.13 & \\
\hline & & & A & 0.08 & \\
T5 & 0.5 & 0.5 & B & 0.17 & 0.17 \\
& & & C & 0.27 & \\
\hline & & & A & 0.39 & \\
T6 & 0.5 & 1 & B & 0.46 & 0.43 \\
& & & C & -- & \\
\hline
\end{tabular}

-The association of marigold with arbuscular mycorrhizae, under the conditions of the experiment, did not present significant differences with respect to the total lead extraction carried out by the plant without inoculating.

-The association of marigold with EDTA did show significant differences with respect to the total lead extraction carried out by the plant alone. The plants to which EDTA was added extracted higher amounts of lead; however, due to the high concentrations of lead in the organism, they presented deficiencies in their physiological development.

-The association of marigold with arbuscular mycorrhizae and EDTA, under the conditions of the experiment, did not present significant differences with respect to the total lead extraction carried out.

\section{References}

Amna, Masood, S., Syed, J.H., Munis, M.F.H., \& Chaudhary, H.J. (2015). Phyto-extraction of Nickel by Linum usitatissimum in Association with Glomus intaradices. International Journal of Phytoremediation, 17(10), 981-987. https://doi.org/ $10.1080 / 15226514.2014 .989311$

Castillo, O.S., Dasgupta-Schubert, N., Alvarado, C.J., Zaragoza, E.M., \& Villegas, H.J. (2011). The effect of the symbiosis between Tagetes erecta L. (marigold) and Glomus intraradices in the uptake of Copper(II) and its implications for phytoremediation. 
New Biotechnology, 29(1), 156-164. https://doi. org/10.1016/j.nbt.2011.05.009

Corzo, I., \& Velásquez, M. (2014). El Plomo y sus efectos en la salud. Acta Médica del Centro, 8(3), 141-148.

Delgadillo-López, A.E., González-Ramírez, C.A., PrietoGarcía, F., Villagómez-Ibarra, J., \& AcevedoSandoval, O. (2011). Fitorremediación: Una alternativa para eliminar la contaminación. Tropical and Subtropical Agroecosystems, 14(2), 597-612.

Diez, L. (2008). Fitocorrección de suelos contaminados con metales pesados: Evaluación de plantas tolerantes $y$ optimización del proceso mediante prácticas agronómicas. [Doctoral thesis, Universidad de Santiago de Compostela].

Duarte, A., Cachada, A., \& Rocha-Santos, T. (2017). Soil pollution-From monitoring to remediation. Cambridge: Academic Press.

Duñabeitia, M., Rodríguez, N., Salcedo, I., \& Sarrionandia, E. (2004). Field mycorrhization and its influence on the establishment and development of the seedlings in a broadleaf plantation in the Basque Country. Forest Ecology and Management, 195(1-2), 129139. https://doi.org/10.1016/j.foreco.2004.02.038

Gaur, A., \& Adholeya, A. (2004). Prospects of arbuscular mycorrhizal fungi in phytoremediation of heavy metal contaminated soils. Current Science, 86(4), 528-534. https://www.jstor.org/stable/24107905

Huang, J.W., Chen, J., Berti, W.R., \& Cunningham, S.D. (1997). Phytoremediation of Lead-Contaminated Soils: Role of Synthetic Chelates in Lead Phytoextraction. Environmental Science and Technology, 31(3), 800-805. https://doi.org/10.1021/ es9604828

Juárez, H. (2006). Contaminación del Río Rímac por metales pesados y efecto en la agricultura en el Cono Este de Lima Metropolitana. [Master's thesis, Universidad Nacional Agraria La Molina]

Lombi, E., Zhao, F.J., Dunham, S.J., \& McGrath, S.P. (2001). Phytoremediation of Heavy Metal Contaminated Soils: Natural Hyperaccumulation versus Chemically Enhanced Phytoextraction. Journal of Environmental Quality, 30(6), 19191926. https://doi.org/10.2134/jeq2001.1919

Marchiol, L.; Sacco, P.; Assolari, S.; Zerbi, G. (2004). Reclamation of polluted soil phytoremediation potential. Water, Air, and Soil Pollution, 158(1), $345-356$.

Mendez García, E. F. (2009). El Cultivo de Marigold (Tagetes erecta L.) en el Perú: Presente y futuro. [Master's thesis, Universidad Nacional Agraria La Molina]

Servicio de Agua Potable y Alcantarillado de Lima SEDAPAL (2009) Convenio de Cooperación Institucional No. 002-2009 / MINSA-SEDAPAL

Shah, K., Mankad, A.U., \& Reddy, M.N. (2017). Lead Accumulation and its Effects on Growth and Biochemical Parameters in Tagetes erecta L. Int. J. Life. Sci. Scienti. Res., 3(4), 1142-1147. https://doi. org/10.21276/ijlssr.2017.3.4.7

Sinhal, V.K., Srivastava, A., \& Singh, V.P. (2010). EDTA and citric acid mediated phytoextraction of $\mathrm{Zn}$, $\mathrm{Cu}, \mathrm{Pb}$ and $\mathrm{Cd}$ through marigold (Tagetes erecta). Journal of Environmental Biology, 31(3), 255-259.

Tello, L., Jave, J., \& Guerrero, J. (2018). Análisis de Cuantificación de Plomo en Suelos de Parques Recreacionales de la Ciudad de Lima-Perú. Ecología Aplicada, 17(1). https://doi.org/10.21704/ rea.v17i1.1168

Zhao, F.J., Hamon, R.E., Lombi, E., McLaughlin, M.J., \& McGrath, S.P. (2002). Characteristics of cadmium uptake in two contrasting ecotypes of the hyperaccumulator Thlaspi caerulescens. Journal of Experimental Botany, 53(368), 535-543. https://doi. org/10.1093/jexbot/53.368.535 